\title{
O ROMANCE OS ANÕES: A AMAZÔNIA SOB A SÁTIRA DE HAROLDO MARANHÃO
}

\section{THE NOVEL OS ANÕES: THE AMAZON UNDER HAROLDO MARANHÃO'S SATIRE}

\author{
Elisangela Ribeiro Oliveira ${ }^{1}$, Maria de Fatima do Nascimento ${ }^{2}$
}

\begin{abstract}
RESUMO: O presente artigo discute a sátira no romance Os anões (1983), do escritor paraense Haroldo Maranhão. A referida obra sugere a pauta dos grandes projetos desenvolvimentistas propostos pelos governos militares para a região amazônica do Brasil entre as décadas de 1970 e 1980, especialmente na Amazônia paraense. Vale ressaltar que é pelo discurso jocoso e indignado da sátira que Haroldo Maranhão denuncia os piores problemas enfrentados pelos paraenses e belenenses, ou seja, o descaso dos governos com a população do Pará e com o espaço amazônico, bem como a exploração de riquezas naturais e da força de trabalho do homem local, a supervalorização das aparências e a busca incessante pelo poder, seja econômico, social ou político, que maculam as instituições brasileiras, a saber: a igreja, a família, a justiça e a política.
\end{abstract}

PALAVRAS-CHAVE: Haroldo Maranhão; Os anões; sátira; Amazônia

ABSTRACT: This article discusses the Amazonian romantic context of Os anoes (1983), by Haroldo Maranhão's writer from Pará. Reading the novel suggest that the guidelines for major development projects proposed by the military governaments for the Amazon region between the years 70 to 80 . However, it is through the humorous and indignant speech of the satire that Haroldo Maranhão denounces the worst problems faced by the people of Pará and Belém, that is, the neglect of governments with the local population and the Amazonian space, as well as the exploitation of natural wealth and the strength of man, the overvaluation of appearances and the incessant search that Brazilian institutions: the church, the family, the justice and the politics.

Keywords: Haroldo Maranhão; Os anões; satire; Amazon

\section{Introdução}

Haroldo Maranhão (1927-2004), romancista paraense, nascido em Belém, iniciou sua carreira como escritor de romance somente aos 55 anos. A sua trajetória de ficcionista foi curta, mas muito produtiva, escrevendo variados gêneros ficcionais como contos, crônicas, novelas e romances, muitos dos quais foram premiados. O livro de crônicas A estranha xícara (1968) foi sua primeira publicação, seguido de Chapéu de três bicos (1975), Voo de galinha (1978), Flauta

\footnotetext{
${ }^{1}$ Doutoranda do PPG em Letras. Professora da rede pública do Estado do Pará

${ }^{2}$ Doutora em Teoria e História Literária pela UNICAMP, com Pós-Doutorado na Faculdade de Filosofia, Letras e Ciências Humanas da Universidade de São Paulo. Professora da Faculdade de Letras da UFPA.
} 
de bambu (1979), para citar alguns gêneros curtos. Mas foi com os romances que ele alcançou maior projeção, a exemplo dos seguintes: O tetraneto del-rei: o torto - suas idas e venidas (1982); Os anões (1983); Rio de raivas (1987); Cabelos no coração (1990) e Memorial do fim: a morte de Machado de Assis (1991). Sua última obra publicada foi o livro de contos Nariz curvo (2001).

Dois dos cinco romances haroldianos discutem questões da Amazônia, Os anões e Rio de raivas. Nessas duas narrativas são demonstradas as mazelas da Amazônia urbana, revelando o sentimento mais profundo e, por vezes, mais desprezível das personagens que circulam no espaço romanesco da Amazônia paraense, as quais demonstram o desejo de garantir a continuidade de seus prestígios a qualquer custo, seja no ambiente fechado de uma grande empresa, seja no ambiente mais amplo, a cidade de Belém do Pará.

Nesse sentido, temos por objetivo, no artigo ora proposto, refletir a respeito tanto da sátira presente no romance Os anões quanto do correspondente procedimento de composição por parte do ficcionista. Este denuncia o mal-estar causado pelos desvios de comportamentos e atitudes não aceitos pela ética e pela moral da sociedade, mas, segundo a obra, vividos desregradamente por homens e instituições sociais na Amazônia. Para embasamento teórico, tomamos estudiosos da sátira, a saber: Carratore (1962), D’Onofrio (1969), Vitorino (2003), Lukács (2011) e Debailly (2018).

\section{Considerações sobre a sátira}

Para que uma obra literária seja definida como sátira, é necessário identificar as propriedades satíricas presentes no texto, isto é, observar como tais propriedades, que hoje são entendidas como um procedimento, foram utilizadas pelo autor e com que propósito. A esses procedimentos chamamos também "atitudes satíricas".

De acordo com Debailly (2018, p. 19), entre as atitudes satíricas, duas são principais e permeiam toda sátira literária, quais sejam, "a comicidade e a indignação", uma vez que não existe sátira sem essas duas atitudes, porque esses são os dois procedimentos mais genuínos da sátira que reverberam o comportamento do escritor satírico diante de uma realidade maculada que se quer suplantar pelo argumento do riso e do combate.

Aliás, os estudos sobre a origem da sátira latina demonstram que "humor e crítica social" são marcas herdadas no momento do surgimento desse gênero literário em Roma. Primeiramente com Lucílio (180-102 a.C), um poeta satírico que renovou a poesia latina por meio da linguagem, introduzindo nela uma forma especial de crítica social, os chamados 
Sermones $^{3}$, os quais transformaram os textos da satura latina ${ }^{4}$ e inauguraram a sátira latina. De acordo com Carratore (1962), a novidade de Lucílio se deu pela introdução de mudanças tanto na forma da poesia, com versos em hexâmetro, quanto nos temas da poesia, que passaram a criticar a dura realidade cotidiana daquela sociedade. O novo ritmo e o caráter moralizante dado à poesia por Lucílio tornaram o gênero mais popular.

Posteriormente a Lucílio, houve dois importantes poetas satíricos que contribuíram para o amadurecimento da sátira latina: Horácio (65-8 a. C.) e Juvenal (67 a 140 d. C), os quais se inspiraram em Lucílio. Entretanto, Carratore (1962) afirma que o primeiro não aderiu à linguagem prolixa, preferindo a escrita simples, com um refinado senso de humor, que era mais coerente com seu modo de viver e de estimular a reflexão dos valores morais.

Embora Juvenal seja também poeta satírico inspirado em Lucílio, assemelhando-se a ele pela adesão ao discurso moralizante, o discípulo superou o mestre, uma vez que seu tom satírico se tornou mais demolidor, pois nele acentuou a agressividade, ampliando o caráter mordaz do discurso moralizante. Isso porque "diante da iniquidade, da corrupção e da libertinagem”, que reinavam em Roma, naquela época, via-se obrigado a escrever com ira e indignação, conforme ressalta Vitorino (2003, p. 49).

A sátira surge assim como um produto social que buscou sempre a adesão do leitor, passando a ter dois caminhos, um mais leve, o riso faceiro e galhofeiro, o que podemos chamar de horaciano e o riso zombador e irônico, juvenaliano. Mas alguns filósofos alemães do século XIX, ao se debruçarem sobre questões da sátira, atribuíram maior valor estético às obras em que os escritores satíricos reconheciam o mal da sociedade, mas se mantinham distantes do problema, sem demonstrar na obra nenhuma espécie de sentimento de revolução, de mudança, uma vez que a sociedade burguesa daquele momento queria evitar o questionamento de sua classe, por isso, segundo Lucáks (2011, p. 166), filósofos como Vischer "atacam violentamente o extravasamento da bílis" nas obras, uma vez que, para ele, demonstrar o ímpeto não dava credibilidade ao artista.

\footnotetext{
${ }^{3}$ Segundo os estudos de Carratore (1962), sermones ou conversas diz respeito a um conjunto de textos que circulavam na Grécia Antiga na forma de versos, tratando de assuntos diversos muito descontraídos e zombeteiros. Afirmando ainda que os sermones se originaram da satura latina e eram coletânea de 18 composições, misturando "pequenos contos, anedotas, confidências, cartas, diálogos, repletos de referências a pessoas e acontecimentos da época" (CARRATORE, 1962, p. 44-45).

${ }^{4}$ Ainda, conforme Carratore (1962, p. 44), A satura latina também fazia parte da cultura romana, mas esta era anterior aos sermones e era marcada pela "miscelânea da assuntos" e pela "variedade de metros", como ocorria nas poesias de Ênio e Pacúvio.
} 
No entanto, outros estudos também vão endossar que o contexto social dita a necessidade de aumentar ou não o volume do grito de revolta, a exemplo das poesias de tom mais indignado, como observou Salvatore D’Onófrio sobre a poesia de Juvenal:

\begin{abstract}
Ninguém melhor do que o poeta Juvenal soube apontar a causa motivadora do escritor satírico: indignação, isto é, a revolta contra o vilipêndio dos princípios sagrados do bem, da justiça, do amor, da pátria, da religião, da família. Numa gama variada de sentimentos, que vai da violência da inventiva até ao fino humorismo, o autor satírico serve-se do ridículo para a finalidade catártica da correção dos costumes (D’ONÓFRIO, 1968, p. 16).
\end{abstract}

Desse modo, a sátira, seja mais galhofeira, seja mais ácida, passou a ter papel fundamental para denunciar as mazelas de uma sociedade em dissonância com o bem-estar social de seus membros. Contudo, Debailly (2018, p. 20) ressaltou que os poetas satíricos da Antiguidade precisavam fazer um esforço a mais para legitimar o riso e a indignação como forma de combate ao desvio de conduta, caso contrário seriam acusados de se utilizarem da zombaria e da indignação de forma arbitrária, reduzindo seu discurso e alimentando "a fofoca, a calúnia e invectiva". Todavia, com a chegada da modernidade, a sátira não se manteve como um recurso exclusivo da poesia, passando a ser um procedimento recorrente nos diversos gêneros que se popularizam a partir do século XIX, sobretudo os romances. Os romancistas, que se utilizam da sátira como um procedimento precisam de muito talento para que suas figurações superem o nível do humor, levando os leitores a uma reflexão da realidade social.

A sátira continua sendo um processo rico de criação literária, envolvendo crítica social e comicidade. Entretanto, Debailly (2018, p.19) postula que a comicidade é a arma preferida da sátira, sobretudo porque é ela que aciona outros recursos, tais com humor, ironia e paródia. Estes procedimentos ajudam a dar forma à realidade que se quer combater, o que pode gerar um humor mais pesado, isto é, mais indignado, ou mais galhofeiro, atenuado pelo riso.

Outro aspecto importante da sátira é o seu conteúdo, o qual, sendo um extrato social, torna evidente a diferença na compreensão das questões históricas entre as classes dominantes e as classes oprimidas, segundo Lukács (2011, p. 180), isso implica afirmar que o autor satírico combate, mesmo que inconscientemente, uma sociedade de classes e, ao fazer isso, trata o objeto satirizado com maior ou menor profundidade, a depender da classe com a qual ele se identifica ideologicamente. Analisando a percepção sobre a Revolução Francesa em textos de sátira e comédia do século XIX, o crítico afirma:

[...] a contradição que opõe o desenvolvimento das forças produtivas às relações de produção que entravam este desenvolvimento, oposição necessariamente destinada a aprofundar constantemente, privará cada vez mais os defensores das relações de 
produção que envelhecem, ou que já envelheceram, de toda compreensão das forças que revolucionam as sociedades. Decerto, os defensores do mundo que morre também produzem sátira - e o fazem em grande número. Toda classe dominante luta também com as armas do sarcasmo e da ironia contra a classe que ela oprimiu e explorou, mas que agora entra em cena com a ambição de tomar seu lugar de classe dominante da sociedade (LUKÁCS, 2011, p. 180-181).

Podemos depreender dos estudos desses autores que é o tempo observado pelo escritor que exige dele a sátira, sobretudo quando o tempo é de elevada crise social, pois outra forma literária parece não figurar efetivamente os vícios essenciais da classe social a qual o escritor da sátira quer combater.

\section{Haroldo Maranhão e o discurso satírico indignado do romance Os anões}

A Ditadura Militar no Brasil ocorreu entre os anos de 1964 e 1985. Foi um período em que se negou os direitos políticos e sociais ao povo brasileiro, com perseguição política, censura e a liberdade é cerceada, de acordo com Franco (1998). Poetas, romancistas, músicos e artistas de modo geral, políticos, pensadores e opositores de tal regime ditatorial, foram perseguidos, muitos torturados e mortos, vários opositores foram obrigados a se exilarem em outros países. As pessoas comuns também não podiam se manifestar contra o governo, durante o período de tal regime.

Nesse sentido, os produtores de literatura na Amazônia paraense desse período não ficaram alheios a todas as questões referidas, conforme podemos observar no romance $O$ s anões (1983), de Haroldo Maranhão, publicado quando vivíamos quase no fim do regime, portanto num momento mais propício para que o romancista dividisse sua angústia com os leitores, ao mesmo tempo em que denunciava a devastação e degradação tanto da Amazônia quanto do homem amazônico. A sua observação perscrutadora e crítica da sociedade urbana daquele período revela-nos um ficcionista que soube pinçar com muita lucidez o que marcava a consciência social em Belém do Pará, em um momento de crise política, vivenciado no século $\mathrm{XX}$, pensando questões políticas e socioambientais, as quais a sociedade precisava refletir.

Os anões é um romance de 29 capítulos, cujo tempo da narrativa sugerido coincide com o período em que a Amazônia foi palco de projetos desenvolvimentistas, incentivados pelos governos militares. Isso fica sugerido por meio do espaço do romance, ou seja, a fábrica de celulose Janari Preensora Ilimitada, instalada na região do Pará por um empresário americano, o milionário Mr. Ezequiel G. Wolfgang, personagem que é indiferente aos recursos humanos e naturais dos quais dispõe: os funcionários paraenses da empresa e a floresta amazônica. 
Apesar de Haroldo Maranhão morar longe de sua cidade natal, tendo em vista que na época da escrita desse romance, o nosso ficcionista residia no Rio de Janeiro, sua memória do Pará e da cidade de Belém foi evocada em Os anões, trazendo para o espaço romanesco lugares conhecidos daqueles que residem na cidade, a exemplo de nomes de empreendimentos, de bares, de restaurantes, de hotéis, de empresas que sugerem aquelas que já existiam em Belém e outras que se instalaram no Pará no período ditatorial, bem como nomes, que sugerem as áreas de coberturas florestais onde os projetos se instalaram, como o empreendimento da Jari em Monte Dourado, no Pará. Nesses espaços, desfila uma infinidade de tipos sociais, tais como: empregados de altos cargos da empresa estrangeira, empresários, militares, jornalistas, repórteres, advogados, engenheiros, geólogos, políticos, médicos, motoristas, garçons, cafetões, garotas de programas, entre outros.

O romance em análise destaca personagens vindas de outras partes do país para trabalhar na Amazônia, com prestígio por terem formação, experiência e atitudes firmes com seus subordinados nas áreas estratégicas da referida empresa de Mr. Wolfgang, dono de parte do Estado do Pará. A título de exemplo, citamos o Capitão Equino Suspicaz, que pedia para ser chamado de Professor, uma personagem importante da empresa do estrangeiro e vinda do Rio de Janeiro. Essa figura vai ser um dos oponentes da personagem principal da obra. Isso porque o paraense Palmar Demissio Colonho, que é Diretor-Executivo da empresa e chamado pelo narrador de anão, homem de um metro e quarenta de estatura e com muitos desvios de caráter, ao perceber as atitudes de chefia do referido Capitão, suspeita que este poderia ser elevado ao seu posto na empresa e Colonho perder seu importante cargo de Diretor-executivo.

Assim, o Diretor-Executivo Palmar Demissio Colonho, da empresa Janari Preensora Ilimitada, fazia de tudo para se igualar à personagem vinda do Rio de Janeiro, forçando amizade com o Professor, que se esquivava de tal apreço. Por isso, o Diretor-Executivo se corrói de inveja e medo do novo funcionário, que demonstrava conhecimento da sua área de trabalho, executada na empresa com muita competência. Já Palmar Demissio Colonho é demonstrado na obra como uma criatura submissa e bajuladora do patrão, não tendo voz ativa naquilo que executa e não sendo respeitada pelos empregados sob sua chefia.

Essa personagem vive a estressante missão de tentar equilibrar-se no cargo de diretor e ser respeitado pelos demais funcionários. A luta pelo reconhecimento revela o conflito interior dessa personagem, sugerindo que o trabalhador em cargo de chefia, da época em Belém, vive em um ambiente provinciano medíocre, especialmente o Diretor Colonho, que não tem habilidades suficientes para se destacar no cargo que ocupa e por isso precisa adular o patrão e os colegas que se destacam naquilo que fazem. 
Desse modo, a referida personagem sofre não só ao pensar em perder o dinheiro que recebe no cargo que ocupa, mas também de perder o prestígio de ser o Diretor de uma Multinacional, o que é visto por ele como necessidade básica. No momento da morte, percebe o caráter transitório das conquistas materiais, mas em vida Palmar Demisso Colonho não as quer perder. Isso pode ser percebido quando ele afirma que há os que estão "de cima" e os que estão "de baixo", mas ele está "de cima". Isso ele afirma antes de adoecer. Porém, quando tem o ataque e está desfalecido, o narrador demonstra que tudo o que ele fazia para viver aquela vida parece que não valeu a pena: "Estava quieto, Palmar Demisso Colonho emperdigado agora ia, severo e solitário no negro Landau. Não falava, olhava sem ver, pensar não pensava, pouco lhe importando se teriam subido ou descido na Bolsa as ações da Fecalpará” (MARANHÃO, 1982, p. 11).

Porém, contrariando suas expectativas, ele é dado como morto. A partir de então, a personagem percebe que os que o rodeavam eram falsos, que ninguém o respeitava de fato. Todos o tratavam com insignificância. No início da história, o narrador nos antecipa o que mais tarde a personagem descobre, a brutalidade com que os dois, que socorriam a personagem, tentam prender o corpo do diretor desmaiado ao cinto de segurança:

Sargento Domingão desembarcou de má vontade, abriu a porta e com rispidez endireitou o defunto ainda desengonçado. Passou-lhe transversalmente o cinto de segurança, atou com a brutalidade que lhe foi possível, mas Palmar Demisso Colonho nem gemeu. Sargento Domingão repuxou pela nuca os cabelos, e a cabeça se alteou em sinal de mando ou de desdém" (MARANHÃO, 1983, p. 11).

Percebemos que Palmar Demisso Colonho não era respeitado, mesmo sendo um diretor, uma vez que não recebeu de seus conhecidos a comoção natural de quem vê o próximo na agonia. Pelo contrário, a quase certeza de que ele já estivesse morto, estimulou-os a demonstrar o pouco apreço pela vida do colega.

O narrador do referido romance é heterodiegético, conforme Genette (1979), pois, embora ciente de todos os detalhes dos acontecimentos que envolvem suas personagens, não participa deles. Isso porque cede a função da narrativa aos seus personagens, e vemos os acontecimentos sob outra perspectiva, a da personagem. Dessa forma, conhecemos a revolta de Palmar Demisso Colonho ao perceber que era menosprezado por seus subordinados, que o cercam após a sua síncope. Não é somente o narrador que nos conta, é a própria personagem desfalecida, como se estivesse pensando, ouve e percebe tudo o que se passa ao seu redor e 
condena as atitudes desumanas com que é tratado, demonstrando também a sua capacidade de violência:

\begin{abstract}
Queria que estivesse aqui o Quixadá, que eu ordenava: mete a peixeira nos três filhos da puta, por minha conta. Pode deixar comigo, Quixadá, enfia a peixeira, mas enfia para estrebucharem sofrendo, empurra a lâmina e mexe na carne para sofrerem mesmo, $[\ldots]$ quero que morram se torcendo de dor, esses frescos miseráveis que não sabem respeitar o patrão (MARANHÃO, 1983, p. 113).
\end{abstract}

De modo semelhante, conhecemos também a truculência da personagem Dr. Gazil Vital, médico da empresa, ao ver que o motorista e o Sargento Domingão, funcionários da empresa, trouxeram Palmar Demisso Colonho desmaiado, como se fosse um "defunto" para ser examinado na casa do médico. Este não gostou, como se o colega seu chefe maculasse o seu espaço residencial, reportando-se ao colega diretor que chega carregado, da seguinte forma:

\footnotetext{
"No chão, merda. No chão." Que eu já estava mais do que enfezado, não posso dizer palavra cabeluda, mas já estava puto da vida com o defuntinho atirado em meus braços, logo depois da porra do meu almoço, quando eu devia era estar me embalando na bosta da minha rede (MARANHÃO, 1983, p. 39).
}

O profissional não se compadece do estado de Colonho, decretando de imediato sua morte, sem ao menos fazer exames minuciosos. Contrariando a afirmação do narrador, que confirmava que Palmar Demisso Colonho ainda vivia, porém "não conseguia mexer-se. Enxergava-os, mas nem as mãos podia levantar a um palmo que fosse do chão melado de graxa, as costas geladas que seria capaz de pegar uma bruta pneumonia" (MARANHÃO, 1982, p. 112). E após tanto esforço para ser ouvido e respeitado, a personagem sentiu-se fraca, fria, gelada. Palmar Demisso Colonho foi morrendo aos poucos e tornou-se de fato um defunto.

Como dissemos, a comicidade e a crítica social são elementos imprescindíveis à sátira literária. Neste sentido, vale ressaltar a construção do discurso moralizante haroldiano. $\mathrm{O}$ autor sabe que sua crítica aos costumes e à sociedade paraense é ácida e demolidora em Os anões, porque nessa obra ele expõe com muita veracidade várias condutas condenáveis e muito caras à sociedade: o desprezo pela vida humana, o apego aos bens materiais, a busca por status, a inveja, a exploração sexual, entre outros vícios denunciados.

A indignação que é suscitada ao se perceber que uma personagem vai morrer, porque não recebeu atendimento médico adequado, logo é despistada pela linguagem de baixo calão da personagem, evocando o riso de zombaria e criando uma sátira matizada de comicidade e indignação.

Nessa mescla entre comicidade e indignação, outras atitudes satíricas são acionadas, a exemplo da ironia, do jogo de palavras, do exagero, entre outros procedimentos utilizados nas 
sátiras haroldianas. O nome do Dr. Gazil Vital é uma ironia muito evidente, uma vez que ser médico implica cuidar dos pacientes, proporcionar-lhes o bem-estar. Mas o médico deixa de prestar o serviço vital para o qual foi formado, a preservação da vida. Ao fazer os exames para ver se Palmar Demisso estava vivo, resolveu declará-lo morto com apenas três procedimentos: a verificação das pupilas, a falta de respiração, a não retração dos pés ao fazer cócegas. Após isso, ele fez a seguinte observação: "Mortíssimo. O homem está morto. Não demora muito começa a endurecer. Feder também não vai demorar. E se os senhores querem saber de uma coisa, eu digo: este aí já fedia antes de morrer. Era uma carniça de gravata e paletó" (MARANHÃO, 1983, p. 41).

Semelhantemente, a fábrica de celulose romanceada, Janari Preensora Ilimitada, faz um jogo de palavra com o termo "Ltda", nome jurídico dado às empresas registradas no Brasil em que os sócios têm responsabilidade limitada. Já o termo "Ilimitada" carrega em si a ironia, sugerindo que o dono da empresa, Mr. Wolgang, possuía amplos poderes sobre a região onde estabelece seu negócio, a Amazônia, podendo fazer o que quisesse na Região. Nesse jogo de palavras, Haroldo Maranhão vai construindo seu discurso de denúncia contra a espoliação da Região Amazônica.

Outra ironia mais dura, que sugere a bílis do autor quanto ao tema de espoliação das riquezas amazônicas, é a que se verifica na construção da personagem Mr. Wolfgang. Isso porque o empresário milionário foi escolhido como personalidade do ano pelo "Who'swho in América”, na edição de 1947, por causa de sua excelente atuação na América do Sul, onde ele possuía vários empreendimentos bem sucedidos. No verbete em homenagem ao empresário do ano, por sua trajetória e atuação eficaz na América do Sul são exaltadas:

Incursionou pela pesquisa, lavra exploração, exportação, indústria e comércio de materiais e minérios em geral na África Ocidental. Desenvolveu processos para aumentar a capacidade de carga de aviões de médio porte. Foi pioneiro nas técnicas mais avançadas de desmatamento, em regiões tropicais de arbustos de arbustos alto porte, esgalhados e densificados.

[...]

Imprimiu impulso considerável na avaliação de recursos naturais de áreas de densa cobertura florestal mediante levantamentos aerofotogramétricos" (MARANHÃO, 1983, p 53-54).

Notamos que nesses trechos o que se exalta da personagem é a sua capacidade de identificar a cobertura florestal e destruí-la com eficiência. Por isso, ele escolheu o Brasil e o Pará, encontrando nesse Estado brasileiro uma mão de obra tão nefasta quanto a sua empresa, pessoas que só pensavam em si, no dinheiro, no prestígio e no poder. 
Num dos espaços romanescos do livro aqui analisado, temos o Bar Central. É nele que outras personagens vão fazer uma determinada crítica à exploração da Amazônia, especialmente da Amazônia paraense, a exemplo de Tupã Buriti, personagem caricata que fala muito alto e cujo barulho é seu “cartão de visita”. Seu nome não carrega ironia, mas hipérbole, sugerindo no nome e no modo de falar a sua função básica na narrativa, porque na língua tupi o termo "tupã" remete a trovão, e Buriti remete à palmeira da Amazônia que produz um fruto que serve de alimento para muitas comunidades. É Tupã Buriti quem critica todos os empreendimentos que estavam sendo desenvolvidos na Amazônia. Isso porque ele percebe que não havia desenvolvimento, mas sim espoliação da terra e do povo paraenses.

É na voz alta desse trovão, escandaloso e antipático, na opinião dos frequentadores do Bar Central, que algumas das denúncias de devastação na Amazônia são feitas. Sobre a espoliação dos minérios, ele declara:

O minério de ferro da serra dos Carajás está calculado em 30 bilhões de toneladas. Eu
disse 30 bilhões de toneladas, 30 bilhões de toneladas. Ponham aí, muito lá por baixo,
dois dólares por tonelada. São 60 bilhões de dólares. E por aí vai. E o carvão
siderúrgico? Foi calculado um potencial de 120 trilhões de toneladas de sal-gema
(MARANHÃO, 1983, p. 1005).

Tupã Buriti ainda alerta os demais frequentadores do restaurante sobre a astúcia do estrangeiro que: "É solerte, gringo é solerte." (MARANHÃO, 1983, p. 103), uma referência àqueles que se utilizam de meios desonestos para conseguir riqueza fácil.

A personagem é o grande denunciador, alerta até sobre o contrabando de bebidas praticado por Mêmolo Boccanera, que fazia sucesso com produtos importados superfaturados, os quais faziam sucesso porque, segundo o denunciante, "nesta terra só presta o que vem de fora" (MARANHÂO, 1983, p. 104). O contrabando era alvo de Tupã Buriti, porque a contravenção solapava impostos que poderiam ser investidos em bens e serviços públicos para a população da Amazônia.

Por seu discurso sempre contestador, Tupã Buriti tem um papel importante na trama. No entanto, ironicamente, sua voz estrondosa e latente parecia não ser ouvida, semelhante à voz de Palmar Demisso Colonho, que não era escutada. Eles tentavam denunciar que eram vítimas, sendo que o executivo se voltou mais para o seu problema individual e Tupão, para o coletivo por causa da espoliação das terras, do minério, da madeira do Estado do Pará e das criaturas da terra, que ele percebia como ingênuas e os governos não se importavam com essa situação. 
As vozes das personagens Palmar e Tupã moldam o tom satírico, garantindo um clima moralizador, político e contestador à narrativa. Isso porque as falhas humanas que prejudicam e matam Palmar Demisso Colonho são denunciadas pela vítima, mas ficam somente no seu pensamento mudo de quase defunto. Contudo, a voz incômoda de Tupã Buriti não só denuncia novamente, mas alardeia, apontando as degenerações que se relacionam com o coletivo, como são apontados no excerto abaixo em que a ironia e a paródia tentam disfarçar a verdade mordaz sobre os projetos que vieram para a Amazônia:

Eles atacam de todas as bandas. É. Atacam pra valer. Olha aí a Bethlehem Steel. A United States Steel Corporation. O Hudson Institute. A Janari Preensora Ilimitada. A Fecalpará. A Cupuaçu Hard Stick Limited. A Pupunha Babacadevelha Corporation. O Backside da Puta Que os Pariu Limited." (MARANHÃO, 1983, p. 104)

O deboche é uma clara crítica às várias empresas abertas na Amazônia pela personagem empresária Mr. Wolfgang. O jogo irônico com o nome das empresas revela o tom satírico ácido, porque desmoraliza a aceitação da presença e espoliação estrangeira na Amazônia. Verificamos um rebaixamento, que escarnece todos os projetos de desenvolvimentos para a Amazônia. O insulto proveniente do arranjo lexical "Fecalpará", "Babacavelhacorporation" e "Backside da Puta Que Pariu Limited" desqualificam a imponência dessas empresas romanescas na Amazônia.

Em outro fragmento, Tupã Buriti, novamente evidencia a sua insatisfação com a situação alusiva ao costume social de valorizar tudo que é de fora, criticando inclusive a submissão ao capital estrangeiro:

[...] metem os gadanhos com vontade. O chão é nosso mas as riquezas são deles. Eles chegam, abrem aeroportos, trazem aviões e entopem de minérios, saem, voltam, enchem de novo, o paraíso tropical, a casa da sogra, casa da mãe-joana. Tiram o pau e mijam na casa da gente. A guerra foi ontem, lembram? Eles chegavam, botavam o pé em cima das mesas da terrasse do Grande Hotel. Tinham um clube o USO, que as moças que frequentavam, o pessoal dizia que eram as usadas. Os homens no Pará abrem os braços. As mulheres abrem as pernas (MARANHÃO, 1983, p 105-106).

Desse modo, Haroldo Maranhão elabora seu argumento satírico mais mordaz, em pleno período de Ditadura militar. A personagem Palmar Demisso Colonho, que era para os nossos tempos atuais um "pedófilo", pois era casado, mas tinha vários relacionamentos sexuais com meninas pobres de 11 e 12 anos, porque para ele uma moça de 15 anos já era velha. O narrador, após a síncope da referida personagem, expõe o seguinte: "Palmar Demisso Colonho apreciava as infantas, como dizia, "as minhas infantas", em rompante de campeão de bola de gude. 'De quinze anos, para mim é velha"” (MARANHÃO, 1983, p. 12). 
Em outra passagem do romance, Palmar Demisso Colonho humilha Quixadá, personagem nordestina, uma espécie de capanga de Colonho, pois é essa personagem que arregimenta as meninas crianças para o Diretor-Executivo da empresa americana. Segundo suas palavras: “'Não gostei, Quixadá. Não estou gostando nada. Que é que há? Eu falo grego, falo? Já não te disse que menina de quinze anos tem idade de ser tua avó? É uma velha, de quinze anos pra mim é uma velha"'. Quixadá pede desculpas por um ato infame que realiza para um chefe vil, conforme o excerto a seguir: "'Eu sei, Dr. Colonho. Mas a de 14 anos que eu arranjei era comprida, quase um metro e setenta. As bichinhas estão crescendo que é um estorvo. Bebem chá de bambu. Entre a varapau de 14 e a jita de 15, levei a de 15 . Pensei que o doutor apreciasse. Agradou não. Me desculpe Dr. Colonho" (MARANHÃO, 1983, p. 12).

Na resposta de Colonho dada a Quixadá, vemos a arrogância e a postura nada ética do Diretor-Executivo, da "Janari Preensora Ilimitada", que trata as meninas e seu empregado como objetos, demonstrando que o dinheiro compra tudo e que ele quer meninas crianças, porque tem dinheiro e paga:

Olha, Quixadá: eu pago. Pago ou não pago? Pago. Quem paga quer ser bem servido. E pago bem. É ou não é? Na vida, presta a atenção, há dois tipos de gente: os que estão de cima e os que estão de baixo. Eu estou de cima, Quixadá. Fiz força para chegar aqui e não vou descer não. E quem está de cima, caga as regras. Eu cago as minhas regras. Não suporto falhas, viu? Eu não erro, escutaste? Eu não erro. E perdoar não perdoo ninguém. Estás avisado (MARANHÃO, 1983, p. 12-13).

Contudo, ele tem uma síncope, no momento em que está mantendo relações sexuais com uma menina menor de idade, quando é socorrido por dois funcionários, que não o levaram ao hospital com medo da polícia e da divulgação em jornais. Por isso, levaram-no para a casa do médico da empresa, onde vem a óbito. Todavia, sua morte é muito triste. Isso porque, embora tenha sido uma pessoa vil, poderia ter sido tratado com dignidade pelo médico e pelos dois funcionários da firma, um é o motorista e o outro é o segurança dele, que o socorrem. Porém, o que ocorreu é que passa por muitos dissabores e desrespeito dos seus colegas de trabalho por ter sido uma criatura vil, que não respeitava os outros. Essa atitude dos colegas de trabalho demonstra que o que Palmar Demisso Colonho pratica é visto como atitudes infames para aquele grupo social do romance em apreciação.

Ao final do romance, constatamos a degradação do espaço da floresta Amazônica e da maioria das criaturas que nela vivem, por meio das práticas dos donos do poder, que não se importam com os menos favorecidos e que praticam coisas escabrosas, mas na ficção são reveladas de forma contundente, tendo em vista a escolha das palavras.

A personagem Tupã se encarrega de denunciar as práticas abusivas dos governos e dos empresários, e os delitos praticados por homens comuns que só pensam em dinheiro e em 
lucros. Por isso, a região é tão espoliada, conforme as palavras da personagem Tupã Buriti, se deixarmos, os gringos "mijam na casa da gente", ou seja, no nosso espaço amazônico, subjugando-nos de todas as formas.

\section{Considerações finais}

O romance Os anões expõe o desprestígio da personagem principal Palmar Demisso Colonho da obra, Diretor-Executivo da empresa de Mr. Wolgang, seja do ponto de vista da execução de trabalho, seja do ponto de vista de sua vida moral. Essa questão é observada logo no primeiro capítulo, quando os dois funcionários, motorista e segurança, levam Palmar Demisso Colonho, o anão, desmaiado, até a casa do médico, Dr. Gazil Vital, para que ele o examinasse e tirasse a dúvida se a personagem estava desmaiada ou morta, porém o referido Diretor-executivo é tratado com desprezo.

A narrativa Os anões, de Haroldo Maranhão, retrata uma Amazônia assoberbada pela decadência moral, porque na capital as personagens vivem o desafio de tentar manter-se sempre vitoriosas e com prestígio. Porém, é uma batalha que tem seus dias contados, uma vez que essa busca é vazia, porque todo o auge é transitório, pois, afinal, a personagem principal Palmar Demisso Colonho, que julgava estar "de cima”, morre.

Em $O s$ anões, o escritor paraense discute assuntos comuns, mas dolorosos para a sociedade brasileira que vive o fim da ditadura, assistindo tantas injustiças, a exemplo de assassinatos, exploração sexual de meninas vulneráveis economicamente, desmatamento da Amazônia, entre outras. No entanto, a abordagem desse tema passa pelo filtro indignado da sátira haroldiana, mostrando uma nova forma de denunciar o que se passava na Amazônia e com o homem amazônico.

O romance demonstra a sátira de tom indignado com discurso moralizante contundente. No nível da forma, vários recursos foram usados para satirizar aqueles que buscam o poder a qualquer custo. A ironia foi um deles e serviu para construir um novo discurso sobre questões políticas. Além da ironia, tivemos o exagero na caracterização das personagens, jogo de palavras, críticas e comicidade, causando mal-estar, revolta, indignação no leitor, e, ao mesmo tempo, um riso provocado principalmente pela linguagem.

O riso zombador expõe a náusea que o momento histórico da ditadura provoca. É esse estado nauseante reflexivo que Haroldo Maranhão almeja do seu leitor, uma vez que pode leválo à reflexão sobre as condutas sociais distorcidas e verificadas na exposição direta das falhas de caráter das personagens. 
Na obra temos, um narrador heterodiegético que nos mostra, por meio das personagens, a representação desse homem da Amazônia e os seus dramas. O narrador é solidário com o leitor por apresentar vários pontos de vistas do mesmo episódio. Ficamos sabendo o ponto de vista do Dr. Gazil Vital, quando o defunto chegou à casa dele, mas ficamos sabendo também como se sentiu a personagem Palmar Demisso Colonho ao ser jogado no chão frio daquela garagem para ser examinado. As duas personagens possuem desvio de caráter, porém a falta de humanidade fica mais evidente naquele que podia fazer alguma coisa pela vida de alguém e não o fez, por vingança.

\section{REFERÊNCIAS}

ANDRADE, Oswald. A sátira na literatura brasileira. In: BOAVENTURA, Maria Eugênia (Org.). Estética e política. São Paulo: Globo, 1992.

BAKHTIN. Mikhail. A cultura popular na Idade Média e no Renascimento: o contexto de François Rabelais. São Paulo. Hucitec Editora, 2013.

BIONDO, Delson. Arte de persuadir e fazer rir: O tetraneto del-rei de Haroldo Maranhão. 2009. Tese. 217 f. UFP, Curitiba, 2009.

BRAGA, Júnior. Haroldo Maranhão: O homem infinito da escrita. Documentário. Belém: TV Cultura do Pará, 2007.

BRAIT. Beth. A personagem. - 9a ed.- São Paulo: Contexto, 2017. 2008.

Beth. Ironia: uma perspectiva polifônica. - 2a. ed.- Campinas: Editora da UNICAMP,

D'ONOFRIO, Salvatore. Literatura Ocidental: Autores e obras fundamentais. - São Paulo: Ática, 1968. FA: Revista de linguística, v. 2. FFCL de Marília - Departamento de Letras, 1962.

FRANCO, Renato. Itinerário Político do Romance Pós - 64: A Festa, São Paulo: Fundação Editora da UNESP, 1998.

FAUSTO, Boris. História do Brasil. - 2. ed. São Paulo: Editora da Universidade de São Paulo: Fundação do desenvolvimento do Brasil, 1995.

LUKÀCS, György. Arte e sociedade: escrito estéticos 1932-1967. - 2ed. Rio de Janeiro: Editora UFRJ, 2011.

MARANHÃO, Haroldo. Os anões. Editora Marco Zero: Rio de Janeiro, 1983.

Haroldo. A leitores e a possíveis leitores. Asas da Palavra. Revista da graduação em

Letras. Centro de Ciências Humanas e Educação. Belém: Unama, v. 6, n. 13, 2002. 
NASCIMENTO, Maria de Fatima do. Benedito Nunes: Itinerário crítico de obras de Haroldo Maranhão. In. ALBUQUERQUE. Gabriel Arcanjo Santos; NASCIMENTO. Maria de Fatima do. Poesia e ficção na Amazônia brasileira- Campinas, SP: Pontes Editores, 2017.

A representação alegórica da ditadura militar em O Minossauro, de Benedicto Monteiro: fragmentação e montagem, 2004, 132p. Dissertação de Mestrado (Teoria e História Literária) - Instituto do Estudo da Linguagem (IEL). Universidade Estadual de Campinas (UNICAMP), Campinas, 2004.

NUNES, Benedito. Do Marajó ao arquivo: breve panorama da cultura no Pará. Belém: Ed. UFPA, 2012.

PASCAL Debailly. Poétique de lasatire. In Revista de Estudos Literários do Centro de Literatura Portuguesa, Universidade de Coimbra, 2018, p. 17-36.

VITORINO. Mônica Costa. Juvenal: o satírico indignado. - Belo Horizonte: Faculdade de Letras/UFMG, 2003.

Documentos da internet

CARRATORE. Enzo Del. Introdução ao estudo das sátiras de Horácio. Disponível em: <www.periodicos.fclar.unesp.br/article>. Acesso em 02 de mar. de 2020.

Recebido em 01/06/2020. Aceito em 07/09/2020. 